\title{
Elevated levels of trace elements in cores of otoliths and their potential for use as natural tags
}

\author{
Benjamin I. Ruttenberg ${ }^{1, *}$, Scott L. Hamilton ${ }^{1}$, Michael J. H. Hickford ${ }^{1,2}$, \\ Georges L. Paradis ${ }^{3}$, Michael S. Sheehy ${ }^{1}$, Julie D. Standish ${ }^{1}$, Ofer Ben-Tzvi ${ }^{4,5}$, \\ Robert R. Warner ${ }^{1}$
}

${ }^{1}$ Department of Ecology, Evolution and Marine Biology and Marine Science Institute, University of California, Santa Barbara, California 93106, USA

${ }^{2}$ Marine Ecology Research Group, School of Biological Sciences, University of Canterbury, PB 4800, Christchurch, New Zealand

${ }^{3}$ Department of Geological Sciences and Marine Science Institute, University of California, Santa Barbara, California 93106, USA

${ }^{4}$ The Institute for Nature Conservation Research, George S. Wise Faculty of Life Sciences, Tel-Aviv University, Tel Aviv 69978, Israel

${ }^{5}$ The Interuniversity Institute for Marine Sciences in Eilat, PO Box 469, Eilat 88103, Israel

\begin{abstract}
Variation in the chemical composition of fish otoliths has been used in recent years to address a range of ecological questions, including levels of stock mixing, variation in habitat use, and rates of larval exchange. While some of these questions have been answered with varying success, the degree to which discrete populations are connected via larval exchange remains unknown. To identify larval sources using natural variation in otolith chemistry, we must distinguish and measure the chemical composition of the otolith core, the portion of the otolith formed at the spawning site. Using laser ablation inductively coupled plasma mass spectrometry (LA-ICPMS), we found that the core regions of otoliths from 6 different species of fishes were highly enriched in manganese $(\mathrm{Mn})$, and elevated in magnesium (Mg) and barium (Ba), relative to adjacent regions of the otolith. These patterns were consistent for species drawn from different taxonomic groups, which inhabit temperate and tropical regions, are found in marine and freshwater, and utilize a variety of spawning modes. Variation among species in Mn concentration in the core also corresponds to maternal investment, measured by egg size. These data suggest that core enrichment may be a general characteristic of otoliths, and that the chemical composition of the otolith core is fundamentally different from other regions of the otolith. The localized elemental enrichment of the core underscores the importance of methods that analyze the core region in small, discrete samples if otolith chemistry is used to address questions of larval exchange among populations.
\end{abstract}

KEY WORDS: Otolith chemistry $\cdot$ Otolith core $\cdot$ Trace metal $\cdot$ Trace element $\cdot$ Larvae $\cdot$ LA-ICPMS Resale or republication not permitted without written consent of the publisher

\section{INTRODUCTION}

How connected are marine populations? This remains one of the fundamental unanswered questions in marine ecology. Many marine organisms have a bipartite life cycle, with a short pelagic larval phase and a longer-lived, sedentary adult stage. For most organisms with this life history, dispersal and the resulting potential for population exchange occur ex- clusively in the pelagic larval phase. The fate of these larvae - whether they survive and are retained near their parent population or are dispersed to other populations - will strongly influence population dynamics and appropriate management strategies for exploited populations (Caley et al. 1996).

Despite its importance, rates of larval exchange among populations remain unknown for any species with dispersive marine larvae, in part because of the 
difficulties in tracking small larvae that suffer extremely high rates of mortality. While early work assumed that marine populations were open and well mixed (Sale 1978, Chesson \& Warner 1981, Roughgarden et al. 1985), recent studies have provided evidence that larval retention may be common (Jones et al. 1999, Swearer et al. 1999, Cowen et al. 2000, Barber et al. 2002, Taylor \& Hellberg 2003). Currently, we lack spatially explicit information on actual levels of larval exchange among populations for any marine species.

In order to measure rates of larval exchange among populations, a tag is needed that will allow the identification of larvae spawned at a given site. New applications of techniques in analytical chemistry coupled with environmental variability in the chemical composition of fish otoliths may provide the appropriate tools and tags with which to identify larval sources (Campana 1999, Campana \& Thorrold 2001), and thereby allow us to measure larval exchange among populations. Otoliths are structures in the inner ears of fishes used for balance and hearing, which are composed of a calcium carbonate/protein matrix. Otolith growth occurs through the daily deposition of new layers throughout the life of the fish. Otoliths have 2 major advantages for use as natural chemical tags: (1) certain trace metals from seawater may be incorporated into the calcium carbonate matrix at levels that may be related to their ambient concentrations in the water and ambient temperatures (Fowler et al. 1995, Thorrold et al. 1997, Campana 1999, Bath et al. 2000, Milton \& Chenery 2001b, Elsdon \& Gillanders 2003a), and (2) otoliths are metabolically inert, such that once a layer of otolith material is deposited, it represents a permanent record of the environmental conditions experienced by that fish at a particular time (Mugiya et al. 1991, Campana \& Thorrold 2001).

If the waters surrounding source populations differ in their environmental characteristics (such as water chemistry or temperature), these differences may be permanently recorded in the otoliths of fish from these different populations. To quantify these records and address a number of questions in marine ecology, researchers have utilized inductively coupled plasma mass spectrometry (ICPMS) (Campana 1999, Campana \& Thorrold 2001). This approach has been used to differentiate among spawning stocks (Edmonds et al. 1991, Campana et al. 2000, Milton \& Chenery 2001a, Rooker et al. 2001, 2003), identify individuals that utilized different nursery habitats (Gillanders \& Kingsford 1996, Forrester \& Swearer 2002, Gillanders 2002), and discriminate between dispersed and retained larvae (Swearer et al. 1999). However, to determine the natal site of an individual, the site where a given larva was spawned, 2 pieces of information are required: (1) a spatial atlas of otolith chemical signatures at natal sites, ideally generated using otoliths of near-term eggs or recently hatched larvae from multiple discrete sites prior to dispersal, and (2) the ability to measure that natal chemical signature from post-larval recruits. Emerging research suggests that proxies for natal chemical signature, such as water samples, do not accurately reflect natal chemical signatures taken from pre-pelagic larvae (Warner et al. in press). For species with pelagic larvae, the spatial atlas of the natal chemical signature will therefore require collections of natal otoliths themselves.

With the application of laser ablation ICPMS (LA-ICPMS), it is possible to target and sample the chemical composition of the otolith core specifically (i.e. the portion representing the natal site) and quantify the natal chemical signature of individuals entering a population following the dispersive larval phase. Ideally, comparisons of chemical signatures from natal otoliths and the natal portion of recruit otoliths will enable investigators to identify the natal sites of individual fish and thereby measure population connectivity. Using a similar approach, Thorrold et al. (2001) successfully determined rates of natal homing in the estuarine-spawning weakfish Cynoscion regalis. Weakfish are a particularly good model system for otolith chemistry because newly hatched fry spend up to several months in their natal estuaries that often differ dramatically in their chemical composition (Thorrold et al. 1998). The portion of the otolith formed in the natal estuary is therefore quite large. However, in most species with pelagic larvae, the natal portion of the otolith is usually no larger than $50 \mu \mathrm{m}$ and often much smaller (R. W. Warner et al. unpubl. data). The natal portion of the otolith ultimately forms the core of the otolith as the fish grows. Accurate measurement of the chemical composition of the core in post-settlement fish is essential for the successful application of these techniques to species with pelagic larvae.

However, measuring the chemical composition of otolith cores of post-settlement fish is not a trivial task, in part because the core itself is quite small and imbedded in a 3-dimensional matrix of calcium carbonate. Therefore, it is important to ensure that the core has been sampled. In a recent study, Brophy et al. (2004) reported elevated levels of manganese (Mn) in otolith cores relative to non-core regions of the otolith in 2 species of clupeids from the North Sea, but they found no spatial structure associated with Mn. They suggested that while Mn levels may not be useful for discriminating natal sites, an increase in Mn might serve as an indicator of the core, allowing measurement of other, more informative elements in the natal portion of the otolith.

The objectives of this study were to determine if a core-specific elemental signature exists that can be used to locate the exact position of the core within the 
otolith, and to describe its chemical composition. We report on elevated levels not only of $\mathrm{Mn}$, but also of barium (Ba) and magnesium $(\mathrm{Mg})$ in putative otolith cores relative to adjacent regions of the otolith of new recruits of 6 different species of fishes. The species we sampled are native to temperate and tropical regions in both freshwater and marine environments. They were drawn from 5 different families in 3 orders, including both pelagic and demersal spawners. We found that these patterns of elevated core concentrations of trace metals are qualitatively similar in all species. As such, elevated otolith core concentrations of trace metals may be common in many fish species and should improve our ability to identify the cores of otoliths and ultimately use otolith chemistry as a tool to track patterns of larval retention and larval dispersal.

\section{MATERIALS AND METHODS}

Study systems, study species and collections. We made collections of newly settled or juvenile fish from a number of locations around the world, including New Zealand, the US Pacific coast, the Red Sea, the Galápagos Islands, and St. Croix, US Virgin Islands (Table 1). Our species covered a variety of spawning strategies, including demersal brooders, ovoviviparous brooders, riparian demersal spawners, and pelagic spawners (Table 1). Divers collected fish in situ using hand nets. Newly settled juveniles of Sebastes atrovirens were collected from the kelp canopy in central and southern California, USA. New recruits of Oxylebius pictus, Dascyllus marginatus, Stegastes beebei, and Thalassoma bifasciatum were collected from shallow reefs in southern California, the Red Sea, the Galápagos Islands, and St. Croix, respectively. Post-larval juveniles of Galaxias maculatus, the only species we examined that spawns in freshwater, were collected after reentering rivers on the west coast of New Zealand.

Immediately after capture, all individuals were frozen, with the exception of Dascyllus marginatus from the Red Sea and Stegastes beebei from the Galápagos, which were stored in $95 \%$ ethanol. Results of previous work are equivocal on the impact of storage method on the chemical composition of otoliths (Milton \& Chenery 1998, Brophy et al. 2003, Hedges et al. 2004). However, storage method was consistent within each species (i.e. either frozen or in ethanol). Because our primary interest lies in examining similarities among intraspecific patterns, storage method should not affect our overall conclusions. Both sagittal otoliths were subsequently removed, cleaned of adhering tissue, and stored dry.

Otolith preparation and analysis. One sagitta from each individual was mounted sulcal side up on plastic slides using low-viscosity epoxy resin (Epo-Thin epoxy resin, Buehler). To expose inner growth layers for analysis, sagittae were polished to within 5 to $25 \mu \mathrm{m}$ of the core using a lapping wheel and 9 and $3 \mu \mathrm{m} 3 \mathrm{M}^{\circledast}$ diamond polishing film. We chose to leave at least $5 \mu \mathrm{m}$ between the polished surface and the core to ensure that the core was not removed during preablation procedures and that we were able to sample all material associated with the core. After polishing, we located the core of each otolith visually and measured the distance between the polished surface and the core (in microns) using a calibrated $z$-axis on a compound microscope at 400x. To remove contaminants and proteins from the otolith surface prior to analysis, sagittae were rinsed in ultra-pure water ( $\mathrm{N}$-pure, resistivity $>18.1 \mathrm{M} \Omega$ ), soaked in semiconductor grade $15 \% \mathrm{H}_{2} \mathrm{O}_{2}$ buffered with Suprapur $\mathrm{NaOH}(0.05 \mathrm{~N})$ in acidleached plastic trays for $1 \mathrm{~h}$, rinsed again in N-pure, soaked and sonicated 3 times in N-pure for $5 \mathrm{~min}$, rinsed a final time with $\mathrm{N}$-pure, and air dried in a class100 flow bench.

We used a Finnegan MAT Element 2-sector field ICPMS and a VG-UV microprobe Nd:YAG $266 \mathrm{~nm}$ laser ablation system for chemical analysis. The laser ablation system was outfitted with a helium aerosol carrier gas system in order to increase sensitivity through enhanced production and transfer of ablated particles to the ICPMS (Swearer 2000, Zacherl et al. 2003). Otoliths were placed in the sample cell, and the core was located using a $400 \times$ objective and a video imaging system (see Swearer 2000 for more details). For the purposes of this study, we define the otolith core as the otolith primordium and other otolith mater-

Table 1. List of species used in this analysis, their families, regions where collections were made, and spawning type

\begin{tabular}{|llll|}
\hline Species & Family & Collection location & Spawning type \\
\hline Galaxias maculatus & Galaxiidae & New Zealand & Amphidromous riparian demersal spawner \\
Oxylebius pictus & Hexagrammidae & California & Demersal nest brooder \\
Sebastes atrovirens & Scorpaenidae & California & Ovoviviparous brooder \\
Dascyllus marginatus & Pomacentridae & Red Sea & Demersal nest brooder \\
Stegastes beebei & Pomacentridae & Galápagos Islands & Demersal nest brooder \\
Thalassoma bifasciatum & Labridae & US Virgin Islands & Pelagic spawner \\
\hline
\end{tabular}


ial deposited while the developing larva is still reliant on yolk-derived nutrition, before exogenous feeding begins. Because the core is located at variable depth below the polished surface of the otolith and is usually quite small ( $\sim 30 \mu \mathrm{m}_{i} \mathrm{R}$. W. Warner et al. unpubl. data), we sought to isolate and characterize only the material associated with it. We therefore ablated and analyzed a series of small, discrete pits sequentially in a vertical transect from the otolith surface through the sample over the region we identified visually as the core. Each pit consisted of 8 laser pulses of $0.1 \mathrm{~mJ}$ at $3 \mathrm{~Hz}$, and all pits in a given vertical transect were ablated in a single crater ( $~ 30 \mu \mathrm{m}$ in diameter). Before acquiring data, we pre-ablated using 2 laser pulses to remove any surface contamination. We analyzed solid glass standard reference material (NIST 612) along with the samples to maintain instrument analytical precision; estimates of precision (as \%RSD) were $17 \%$ for $\mathrm{Mg} / \mathrm{Ca}, 15 \%$ for $\mathrm{Mn} / \mathrm{Ca}, 22 \%$ for $\mathrm{Sr} / \mathrm{Ca}$, and $16 \%$ for Ba/Ca. Limits of detection (LOD) were calculated as $3 \times \mathrm{SD}$ of blanks; limits of detection expressed as ratios to mean $\mathrm{Ca}$ intensities yielded $\mathrm{Me} / \mathrm{Ca}$ detection limits of $0.039 \mathrm{mmol} \mathrm{mol}{ }^{-1}$ for $\mathrm{Mg} / \mathrm{Ca}, 3.3 \mu \mathrm{mol} \mathrm{mol}{ }^{-1}$ for $\mathrm{Mn} / \mathrm{Ca}, 0.067 \mathrm{mmol} \mathrm{mol}^{-1}$ for $\mathrm{Sr} / \mathrm{Ca}$, and $0.77 \mu \mathrm{mol}$ $\mathrm{mol}^{-1}$ for $\mathrm{Ba} / \mathrm{Ca}$.

In each sample pit, we collected counts for the isotopes ${ }^{24} \mathrm{Mg},{ }^{48} \mathrm{Ca},{ }^{55} \mathrm{Mn},{ }^{88} \mathrm{Sr}$, and ${ }^{138} \mathrm{Ba}$ in medium resolution mode $(R=3000)$. Molar ratios of analyte to $\mathrm{Ca}$ were calculated using the ratio of each isotope to ${ }^{48} \mathrm{Ca}$ and an elemental mass bias-correction calculated from calibration standards with known analyte-to-Ca ratios. After analysis, we identified the core of each otolith using elevated concentrations of $\mathrm{Mn}$ as a proxy; in most cases, we found 1 pit which had levels of Mn that were 6 to 10 times higher than those surrounding it. It was necessary to use a proxy to identify the core because once ablation began the ablation crater obscured the core visually. Furthermore, each ablation removed variable amounts of material, making it impossible to determine visually which pit corresponded to the core. We calculated the mean of each element in the 3 pits immediately preceding and the 3 pits immediately following this putative core in the vertical transect. We define the pits immediately preceding the putative core in the vertical transect as 'precore' pits and those immediately following the core in the transect as 'post-core.' We used ANOVA to examine differences among pit types (precore, core, and post-core), blocked by sample number, for each element. Data were $\ln$ transformed when necessary to improve normality.

\section{RESULTS}

We considered a sample to have a spike in Mn if the concentration of $\mathrm{Mn}$ in a given pit was increased by at least a factor of 3 over the previous pits. We chose a factor of 3 as our cutoff to define the Mn spike because the few samples that had multiple Mn spikes never had a single pit the value of which was 3 -fold greater than the previous pits. We detected a Mn spike in many, but not all of the otoliths cores we examined. Detection of a Mn spike ranged from 77 to $95 \%$ of otoliths sampled for a given species (Table 2).

To test if the Mn spike corresponded to the core, we plotted the pit number of the putative core (i.e. the pit number in the sequential vertical transect that contained the Mn spike) against the precisely measured distance between the polished surface of the otolith and the core, located and measured visually before ablation using the calibrated $z$-axis of a compound microscope. We found positive relationships between the pit corresponding to the Mn spike and the distance to the core for all species (Table 2, Fig. 1); the regression for Stegastes beebei in Galápagos was marginally significant $(\mathrm{p}=0.05)$, it was significant for Oxylebius pictus and Sebastes atrovirens in California $(\mathrm{p}=0.02$ for both species), and it was highly significant for all other species $(p<0.0001)$. Because the number of pits required to reach the putative core increased with measured distance to the core for all 6 species, we are confident that the observed Mn spike corresponds with ablation of the otolith core.

Once we identified the core using the Mn spike, we compared the concentration of all other elements $(\mathrm{Mg}$, $\mathrm{Sr}, \mathrm{Ba}$ ) among pre-core, core, and post-core pits within each species/region. Trends in differences among pit types for $\mathrm{Mg}$ and $\mathrm{Ba}$ were fairly consistent across all species in all locations. In general, $\mathrm{Mg}$ and $\mathrm{Ba}$ were elevated in the core relative to pre-core and post-core means, and post-core means were higher than precore means (Table 3, Fig. 2). Core concentrations of Mg were significantly higher than pre-core values for

Table 2. Species, sample sizes, percentage of samples that had a Mn spike, and statistics for the regressions between measured distance to the core and pit number of the putative core

\begin{tabular}{|lrcccccc|}
\hline \multirow{2}{*}{ Species } & N & \multirow{2}{*}{$\begin{array}{c}\text { Percent with } \\
\text { Mn spike }\end{array}$} & df & $F$ & Regression statistics & R & $\mathrm{R}^{2}$ \\
\hline Galaxias maculatus & 108 & 95.4 & 92 & 134.9 & $<0.0001$ & 0.60 \\
Oxylebius pictus & 28 & 82.1 & 20 & 6.08 & 0.02 & 0.24 \\
Sebastes atrovirens & 70 & 87.1 & 59 & 5.42 & 0.02 & 0.09 \\
Dascyllus marginatus & 13 & 92.3 & 11 & 170.2 & $<0.0001$ & 0.94 \\
Stegastes beebei & 33 & 90.9 & 29 & 4.19 & 0.05 & 0.13 \\
Thalassoma bifasciatum & 121 & 76.9 & 54 & 24.3 & $<0.0001$ & 0.31 \\
\hline
\end{tabular}



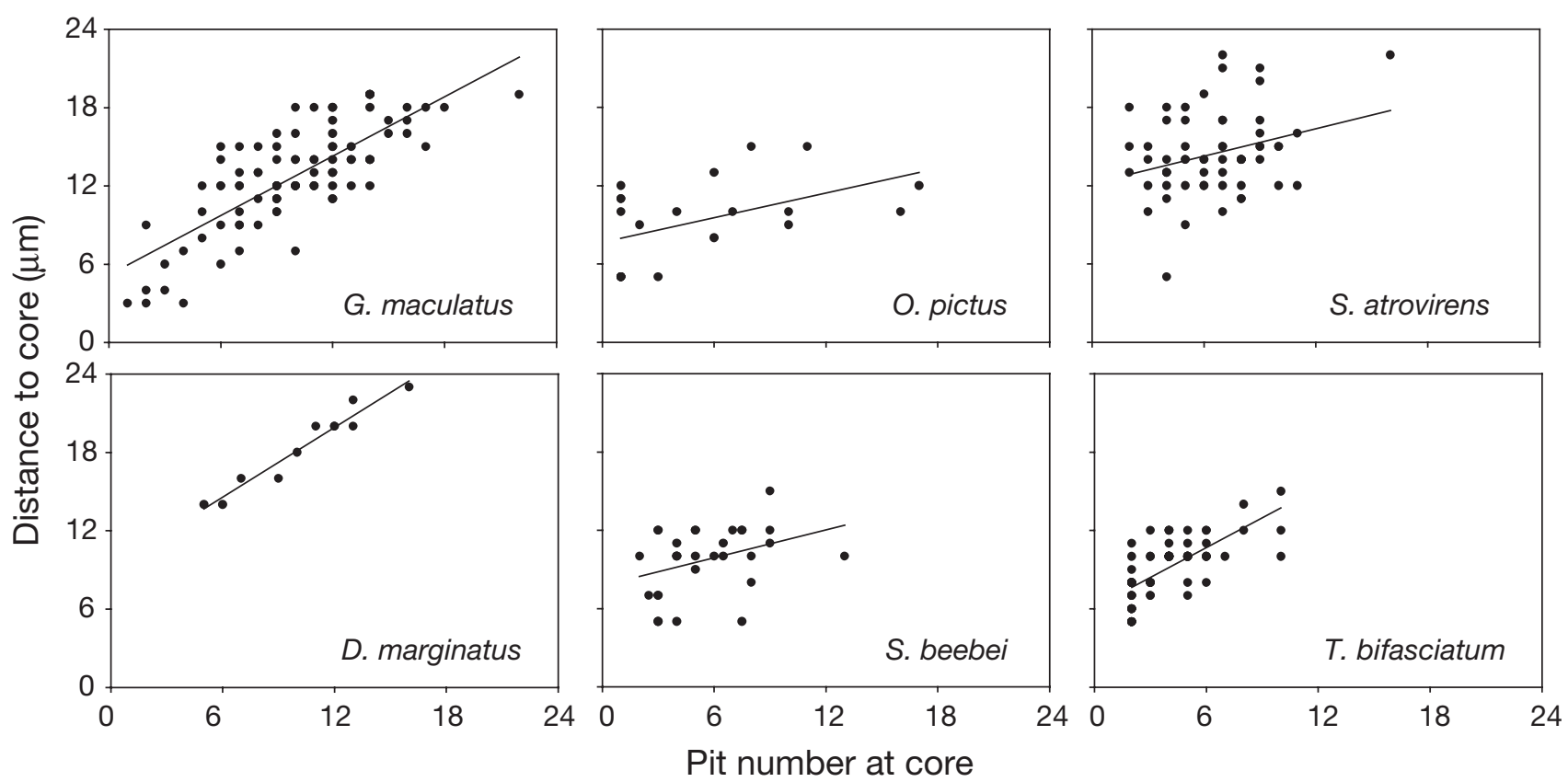

Fig. 1. Regressions of the measured distance from the polished surface of the otolith to the core (in $\mu m$ ) versus the pit number of the putative core. Each plot contains data for a single species. See Table 2 for regression statistics

all species, and core values were higher than post-core values for all species except Oxylebius pictus and Stegastes beebei. Post-core concentrations of Mg were also greater than pre-core concentrations for all species except Sebastes atrovirens. Core concentrations for Ba were significantly higher than pre-core concentrations for all species except $O$. pictus. Post-core means for Ba were also lower than core values, but in most cases these differences were not statistically significant. In addition, post-core values for Ba were significantly greater than pre-core values for all species except $O$. pictus. Trends for $\mathrm{Sr}$ were less clear. In 3 species (Galaxias maculatus, O. pictus, S. atrovirens), $\mathrm{Sr}$ concentrations decreased significantly from precore pits to the core. Sr concentrations increased from pre-core pits to the core in the 3 remaining species, but were significant only for $S$. beebei. Since we identified the core based on a spike in Mn, statistical analyses between core values and either pre-core or post-core values for this element are invalid. However, it is interesting that like $\mathrm{Mg}$ and $\mathrm{Ba}$, post-core concentrations of Mn were higher than pre-core concentrations.

\section{DISCUSSION}

The ability to sample the natal portion of the otolith accurately is critical if we are to use natural chemical markers and otolith chemistry to provide information on larval exchange among populations. Our data demonstrate that a number of elements appear to be more concentrated in the cores of otoliths than in

Table 3. ANOVA table by species and element, compared among pre-core, core, and post-core pits. Results from Mn are not shown; the statistical analyses for $\mathrm{Mn}$ are not valid because core pits were defined by the presence of a Mn spike $\left({ }^{* * *} \mathrm{p}<0.0001\right.$, ${ }^{* *} \mathrm{p}<0.005,{ }^{*} \mathrm{p}<0.05$ )

\begin{tabular}{|c|c|c|c|c|c|c|c|}
\hline \multirow{2}{*}{ Species } & \multirow{2}{*}{$\mathrm{df}$} & \multicolumn{2}{|c|}{$\mathrm{Mg}$} & \multicolumn{2}{|c|}{$\mathrm{Sr}$} & \multicolumn{2}{|c|}{$-\mathrm{Ba}$} \\
\hline & & SS & $F$ & SS & $F$ & SS & $F$ \\
\hline Galaxias maculatus & 2 & 7.694 & $75.7^{* * *}$ & 91.610 & $66.4^{* * *}$ & 4.10 & $16.4^{* * *}$ \\
\hline Oxylebius pictus & 2 & 3.004 & $39.8^{* * *}$ & 0.602 & $23.6^{* * *}$ & 3.06 & $7.8^{* *}$ \\
\hline Sebastes atrovirens & 2 & 3.930 & $37.9^{* * *}$ & 0.809 & $27.8^{* * *}$ & 53.23 & $73.2^{* * *}$ \\
\hline Dascyllus marginatus & 2 & 1.506 & $23.9^{* * *}$ & 0.020 & $5.4^{*}$ & 0.57 & $30.3^{* * *}$ \\
\hline Stegastes beebei & 2 & 7.648 & $54.4^{* * *}$ & 3.413 & $35^{* * *}$ & 36.72 & $43.9^{* * *}$ \\
\hline Thalassoma bifasciatum & 2 & 0.245 & $34.9^{* * *}$ & 4.811 & $10.8^{* * *}$ & 1.84 & $13.3^{* * *}$ \\
\hline
\end{tabular}




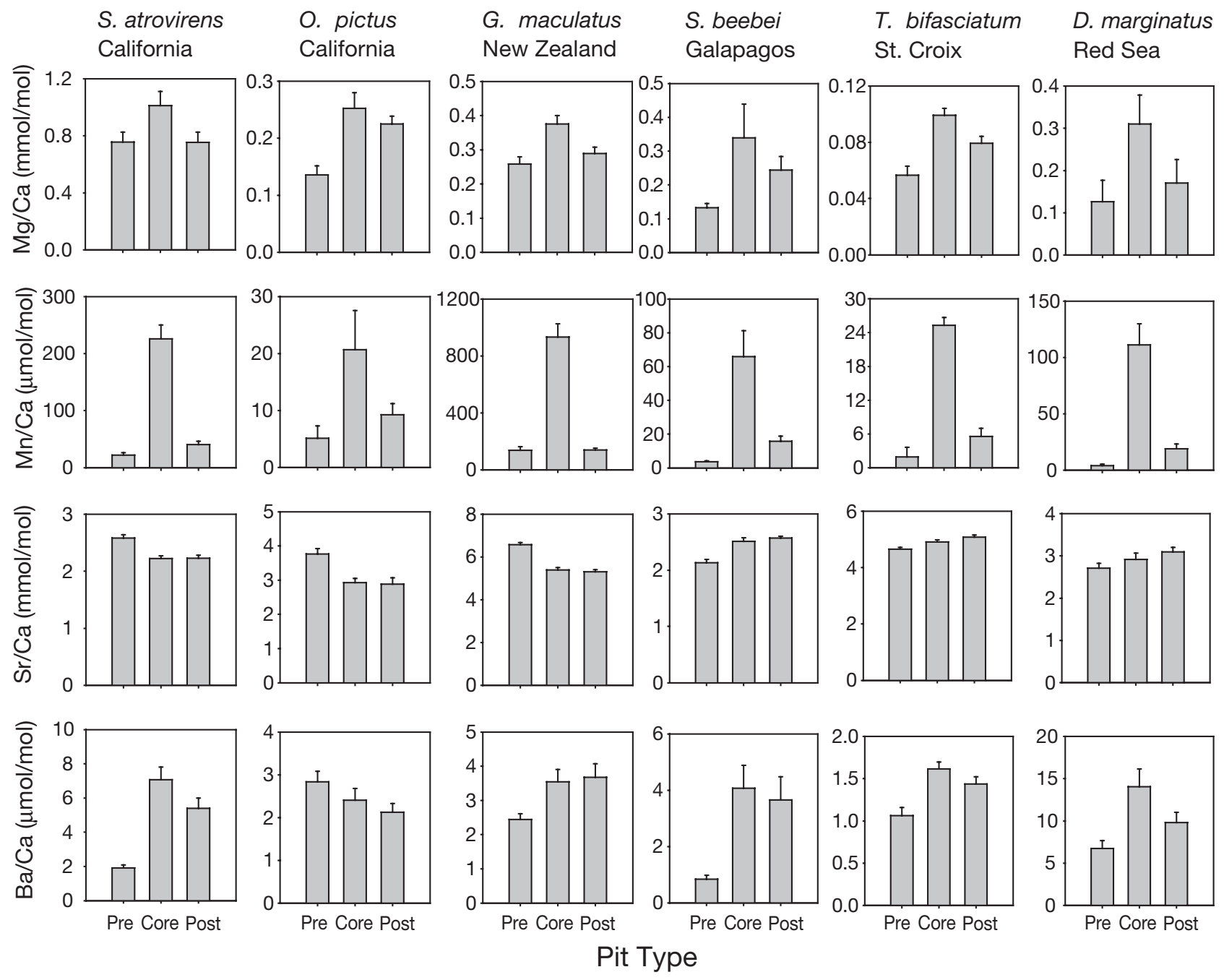

Fig. 2. Mean (+1 SE) elemental concentrations for pre-core pits, the otolith core, and post-core pits for $\mathrm{Mg}, \mathrm{Mn}, \mathrm{Sr}$, and $\mathrm{Ba}$ (rows) for each single species (columns), as concentrations of metal/Ca. Note that the values on the $x$-axis are the same for all plots, but those on the $y$-axis are not

immediately adjacent regions of the otolith. These data confirm the preliminary findings of Brophy et al. (2004) that Mn is highly enriched in the core of clupeid otoliths. We extend these findings to include not only $\mathrm{Mn}$, but $\mathrm{Mg}$ and $\mathrm{Ba}$ as well, and demonstrate that trace metal enrichment of otolith cores occurs in a variety of fish species worldwide with different modes of reproduction and from different habitats. We found a Mn spike in the putative core region of 77 to $95 \%$ of otoliths examined for each species. In nearly all cases where elevated levels of Mn were not detected, we polished close to the actual core $(<5 \mu \mathrm{m})$ and may have unintentionally ablated the core in pre-ablation procedures, or the core region was cracked or otherwise difficult to conclusively identify using the optics of the laser ablation system before ablation began and we may have ablated non-core material.
Furthermore, our data confirm that the Mn spike we used as a proxy for the core does in fact correspond to the core. We found a positive relationship between distance from the polished surface of the otolith to the otolith core and the number of pits required to reach the core for all species. For 3 of our species (with the smallest post-settlement otoliths), this relationship was highly significant ( $p<0.0001$ ); the 3 species for which this relationship was weaker $(0.02<\mathrm{p}<0.05)$ had the largest post-settlement otoliths. Larger otoliths diffuse more of the transmitted light used to visually measure core depth, decreasing the precision of these measurements. Increased measurement error of the depth of the core for these species may have partially obscured the relationship between pit number at the core and measured core depth. 
In addition, variation in amount of material ablated with transect depth could also weaken this relationship. We noted a significant decrease in raw Ca counts, a proxy for material ablated, with increasing pit number (and therefore transect depth) for otoliths of all species except Thalassoma bifasciatum. The energy profile of the laser and the subsequent amount of material ablated in each pit may have decreased with depth, since we did not refocus the laser as transect depth increased. It is also possible that some isotopic fractionation may have occurred as transect depth increased. However, neither decreasing amounts of material ablated nor isotopic fractionation could create the patterns of elemental concentrations we observed among pre-core, core, and post-core pits.

For most elements in most species, concentrations in post-core pits were higher than those in pre-core pits and equal to those in the core in many cases. We attribute the relatively high elemental concentrations in post-core pits to residual material from the core. Some material ablated by the laser may remain in the pit, especially as pits become deeper. Remnant core material partially ablated but not removed as the core is ablated may be remobilized with subsequent ablations, elevating the measured concentrations in postcore pits.

Ultimately, techniques in otolith chemistry are only useful in addressing questions of larval connectivity if there is spatial variation in the chemistry of the core. This variation would necessarily result from differences in the environmental conditions at potential source areas; that is, variation in the chemistry of otolith cores would have to be in some way environmentally driven. A number of studies have found that concentrations of some trace metals in otoliths vary with ambient concentrations (Bath et al. 2000, Milton \& Chenery 2001b, Elsdon \& Gillanders 2003b). However, none of these studies have examined uptake of trace metals at the core. It is unlikely that the dramatic increases in elemental concentrations at the core that we observe are directly related to ambient concentrations, but are instead at least in part ontogenetically driven. In their initial report of $\mathrm{Mn}$ enrichment in otolith cores, Brophy et al. (2004) suggest that increased Mn concentrations at the cores have little or no environmental component and that Mn therefore is primarily useful in detecting the core, not discriminating different source areas. In a study of geographical variation in trace element concentrations in natal otoliths of Sebastes atrovirens, Warner et al. (in press) found that $\mathrm{Mg}, \mathrm{Mn}$, and $\mathrm{Ba}$ were present in higher concentrations in natal otoliths than in adult otoliths from the same sites. Interestingly, only Mn showed environmental variation that was similar to that seen in seawater.
Trends in our species-level data also suggest that ontogenetic shifts and maternal effects may influence the levels of $\mathrm{Mn}$ in the otolith core. Increasing maternal investment (e.g. egg size) may lead to increases in core concentration, at least for some elements. Mean Mn core concentrations for our single pelagic spawner (Thalassoma bifasciatum), with the smallest egg size $(\sim 0.5 \mathrm{~mm})$, are low, usually $<25 \mu \mathrm{mol} \mathrm{mol}{ }^{-1} \mathrm{Ca}$. Mean core $\mathrm{Mn}$ concentration for most of our demersal spawners, with moderate egg sizes (0.7 to $1.2 \mathrm{~mm})$, are between 65 and $225 \mu \mathrm{mol} \mathrm{mol}{ }^{-1} \mathrm{Ca}$. Mean Mn core concentration for Galaxias maculatus, with the largest eggs $(\sim 1.3 \mathrm{~mm})$, is nearly $1000 \mu \mathrm{mol} \mathrm{mol}{ }^{-1} \mathrm{Ca}$. To quantify this relationship, we regressed egg size versus mean core concentration of $\mathrm{Mn}$ for each species and found a weak but positive relationship ( $F=$ 7.26, $\mathrm{p}=0.054, \mathrm{R}^{2}=0.645$ ). However, there is no trend in core concentration versus egg size for any other element in our data set. Other emerging research has also found that maternal effects on the chemical composition of natal otoliths may be much stronger than previously expected (S. Thorrold pers. comm. and unpubl. data). If the chemical composition of otolith cores were not at all under environmental control, but were instead influenced by other factors, such as maternal investment, it would be virtually impossible to use otolith chemistry to identify natal sites of recruits. However, Warner et al. (in press) found significant spatial variation in chemical signatures of pre-natal otoliths collected from 3 different sites, suggesting that chemistry of the otolith cores is at least partly influenced by environment. Still, whether such environmental influences are direct or, in turn, mediated by other factors such as maternal investment are unknown.

The mechanism driving elevated elemental concentrations in otolith cores is also unknown. The enrichment of Mn at the core suggests that this element may be important in processes related to the formation or initial growth of the otolith. Previous research has suggested that initial calcification of the otolith core may require relatively large amounts of protein (Zhang \& Runham 1992, Murayama et al. 2004), and other work has found that $\mathrm{Ca}$ concentration may be lower in the center of the otolith as compared to the edge (e.g. Dove et al. 1996). Increased concentrations of protein and lower concentrations of $\mathrm{Ca}$ could result in high relative concentrations of trace metals if these elements are found in proteins in addition to the calcium carbonate matrix. Elements that replace $\mathrm{Ca}$ in the calcium carbonate matrix as their primary inclusion method into the otolith, such as Sr (Campana 1999), might show little or no change in concentration between the core and adjacent regions of the otolith, as we observe in our data for Sr. However, at present 
we do not have information about whether Mn or any other elements are associated with proteins that are important in initial nucleation and growth of the otolith. Still, the fact that other elements are also elevated, albeit not as dramatically as Mn, confirms that the chemistry of the core is fundamentally different from that of other parts of the otolith and that other parts of the otolith (e.g. edges) are not good proxies for the concentration of the core. Therefore, it appears that we will not be able to use non-core portions of the otolith as surrogates for the core in studies examining questions of larval dispersal.

In summary, we demonstrate that 3 trace metals, Mg, $\mathrm{Mn}$, and $\mathrm{Ba}$, are enriched in the cores of fish otoliths. These patterns are consistent for 6 different species of fishes from a variety of taxonomic groups and environments worldwide. We confirm the findings of Brophy et al. (2004) that Mn may serve as an indicator of the otolith core. Our data suggest that maternal effects on the chemical composition of the core may be quite strong, and, while other recent work suggests that core chemistry appears to have at least a certain environmental component, the relative contributions of maternal and environmental influences remain unknown. The high localized spikes of Mn we observed in otolith cores underscore the need to analyze the area at the core in small, discrete samples. Our method of ablating successive small individual pits to reach the core is designed to sample a very small area and yet may still be incorporating non-core material, diluting the true concentration of elements at the core. Other methods that sample even more material or continuously sample the core may further dilute or miss the core entirely. We suggest that methods and technologies should be utilized to resolve small, discrete regions of the otolith, sampling material exclusively from the 20 to $30 \mathrm{~mm}$ diameter core region. Ultimately, we must be able to measure the chemical composition of otolith cores of post-settlement individuals if we are to apply methods in otolith chemistry to questions of larval dispersal.

Acknowledgements. This work was supported by the Partnership for Interdisciplinary Study for Coastal Oceans (PISCO, funded by the David and Lucille Packard Foundation), the Coastal Environmental Quality Initiative (CEQI, funded by the University of California), the Andrew W. Mellon Foundation, a Fellowship for Coral Reef Research from the International Society for Reef Studies (to B.I.R.), an NSF Predoctoral Fellowship (to S.L.H.), a New Zealand Science and Technology Postdoctoral Fellowship (to M.J.H.H.), and an Academic Minigrant from Environmental Defense (to R.R.W.). We thank N. Kashef, D. Stafford, A. Haupt, M. Burford, G. Thompson, M. Behrens, L. Bellquist, and J. Samhouri for assistance in the field and the laboratory, and we thank 4 anonymous referees for comments on an earlier version of the manuscript. This is PISCO Publication Number 186.

\section{LITERATURE CITED}

Barber PH, Palumbi SR, Erdmann MV, Moosa MK (2002) Sharp genetic breaks among populations of Haptosquilla pulchella (Stomatopoda) indicate limits to larval transport: patterns, causes, and consequences. Mol Ecol 11:659-674

Bath GE, Thorrold SR, Jones CM, Campana SE, McLaren JW, Lam JWH (2000) Strontium and barium uptake in aragonitic otoliths of marine fish. Geochim Cosmochim Acta 64: 1705-1714

Brophy D, Danilowicz BS, Jeffries TE (2003) The detection of elements in larval otoliths from Atlantic herring using laser ablation ICP-MS. J Fish Biol 63:990-1007

Brophy D, Jeffries TE, Danilowicz BS (2004) Elevated manganese concentrations at the cores of clupeid otoliths: possible environmental, physiological, or structural origins. Mar Biol 144:779-786

Caley MJ, Carr MH, Hixon MA, Hughes TP, Jones GP, Menge BA (1996) Recruitment and the local dynamics of open marine populations. Annu Rev Ecol Syst 27:477-500

Campana SE (1999) Chemistry and composition of fish otoliths: pathways, mechanisms and applications. Mar Ecol Prog Ser 188:263-297

Campana SE, Thorrold SR (2001) Otoliths, increments, and elements: keys to a comprehensive understanding of fish populations? Can J Fish Aquat Sci 58:30-38

Campana SE, Chouinard GA, Hanson JM, Frechet A, Brattey $\mathrm{J}$ (2000) Otolith elemental fingerprints as biological tracers of fish stocks. Fish Res (Amst) 46:343-357

Chesson PL, Warner RR (1981) Environmental variability promotes coexistence in lottery competitive systems. Am Nat 117:923-943

Cowen RK, Lwiza KM, Sponaugle S, Paris CB, Olson DB (2000) Connectivity of marine populations: open or closed? Science 287:857-859

Dove SG, Gillanders BM, Kingsford MJ (1996) An investigation of chronological differences in the deposition of trace metals in the otoliths of two temperature reef fishes. J Exp Mar Biol Ecol 205:15-33

Edmonds JS, Caputi N, Morita M (1991) Stock discrimination by trace-element analysis of otoliths of orange roughy (Hoplostethus atlanticus), a deep-water marine teleost. Aust J Mar Freshw Res 42:383-389

Elsdon TS, Gillanders BM (2003a) Reconstructing migratory patterns of fish based on environmental influences on otolith chemistry. Rev Fish Biol Fish 13:219-235

Elsdon TS, Gillanders BM (2003b) Relationship between water and otolith elemental concentrations in juvenile black bream Acanthopagrus butcheri. Mar Ecol Prog Ser 260:263-272

Forrester GE, Swearer SE (2002) Trace elements in otoliths indicate the use of open-coast versus bay nursery habitats by juvenile California halibut. Mar Ecol Prog Ser 241:201-213

Fowler AJ, Campana SE, Jones CM, Thorrold SR (1995) Experimental assessment of the effect of temperature and salinity on elemental composition of otoliths using laser ablation ICPMS. Can J Fish Aquat Sci 52:1431-1441

Gillanders BM (2002) Connectivity between juvenile and adult fish populations: do adults remain near their recruitment estuaries? Mar Ecol Prog Ser 240:215-223

Gillanders BM, Kingsford MJ (1996) Elements in otoliths may elucidate the contribution of estuarine recruitment to sustaining coastal reef populations of a temperate reef fish. Mar Ecol Prog Ser 141:13-20

Hedges KJ, Ludsin SA, Fryer BJ (2004) Effects of ethanol preservation on otolith microchemistry. J Fish Biol 64: 923-937 
Jones GP, Milicich MJ, Emslie MJ, Lunow C (1999) Selfrecruitment in a coral reef fish population. Nature 402: 802-804

Milton DA, Chenery SR (1998) The effect of otolith storage methods on the concentrations of elements detected by laser-ablation ICPMS. J Fish Biol 53:785-794

Milton DA, Chenery SR (2001a) Can otolith chemistry detect the population structure of the shad hilsa Tenualosa ilisha? Comparison with the results of genetic and morphological studies. Mar Ecol Prog Ser 222:239-251

Milton DA, Chenery SR (2001b) Sources and uptake of trace metals in otoliths of juvenile barramundi (Lates calcarifer). J Exp Mar Biol Ecol 264:47-65

Mugiya Y, Hakomori T, Hatsutori K (1991) Trace metal incorporation into otoliths and scales in the goldfish, Carassius auratus. Comp Biochem Physiol C 99:327-331

Murayama E, Takagi Y, Nagasawa H (2004) Immunohistochemical localization of two otolith matrix proteins in the otolith and inner ear of the rainbow trout, Oncorhynchus mykiss: comparative aspects between the adult inner ear and embryonic otocysts. Histochem Cell Biol 121:155-166

Rooker JR, Secor DH, Zdanowicz VS, Itoh T (2001) Discrimination of northern bluefin tuna from nursery areas in the Pacific Ocean using otolith chemistry. Mar Ecol Prog Ser 218:275-282

Rooker JR, Secor DH, Zdanowicz VS, De Metrio G, Relini LO (2003) Identification of Atlantic bluefin tuna (Thunnus thynnus) stocks from putative nurseries using otolith chemistry. Fish Oceanogr 12:75-84

Roughgarden J, Iwasa Y, Baxter C (1985) Demographic theory for an open marine population with space-limited recruitment. Ecology 66:54-67

Editorial responsibility: Otto Kinne (Editor-in-Chief), Oldendorf/Luhe, Germany
Sale PF (1978) Coexistence of coral reef fishes - a lottery for living space. Environ Biol Fishes 3:85-102

Swearer SE (2000) Self-recruitment in coral reef fish populations. PhD thesis, University of California, Santa Barbara, CA

Swearer SE, Caselle JE, Lea DW, Warner RR (1999) Larval retention and recruitment in an island population of a coral-reef fish. Nature 402:799-802

Taylor MS, Hellberg ME (2003) Genetic evidence for local retention of pelagic larvae in a Caribbean reef fish. Science 299:107-109

Thorrold SR, Jones CM, Campana SE (1997) Response of otolith microchemistry to environmental variations experienced by larval and juvenile Atlantic crocker (Micropogonias undulatus). Limnol Oceanogr 42:102-111

Thorrold SR, Jones CM, Swart PK, Targett TE (1998) Accurate classification of juvenile weakfish Cynoscion regalis to estuarine nursery areas based on chemical signatures in otoliths. Mar Ecol Prog Ser 173:253-265

Thorrold SR, Latkoczy C, Swart PK, Jones CM (2001) Natal homing in a marine fish metapopulation. Science 291: 297-299

Warner RR, Swearer SE, Caselle JE, Sheehy MS, Paradis GL (in press) Natal trace-elemental signatures in the otoliths of an open-coast fish. Limnol Oceanogr

Zacherl DC, Paradis G, Lea DW (2003) Barium and strontium uptake into larval protoconchs and statoliths of the marine neogastropod Kelletia kelleti. Geochim Cosmochim Acta 67:4091-4099

Zhang Z, Runham NW (1992) Initial development of Oreochromis niloticus (Teleostei, Cichlidae) otoliths. J Zool (Lond) 227:465-478

Submitted: November 1, 2004; Accepted: May 10, 2005

Proofs received from author(s): June 28, 2005 